\title{
The Use of the Eight-Year Cycle in the Early Malay Calendar
}

Baharrudin Zainal, Zurita Mohd Yusoff, Jamalluddin Hashim, Wan Ismail Wan Abdullah

To Link this Article: http://dx.doi.org/10.6007/IJARBSS/v10-i11/8200 DOI:10.6007/IJARBSS/v10-i11/8200

Received: 10 September 2020, Revised: 12 October 2020, Accepted: 16 November 2020

Published Online: 29 November 2020

In-Text Citation: (Zainal et al., 2020)

To Cite this Article:Zainal, B., Yusoff, Z. M., Hashim, J., \& Abdullah, W. I. W. (2020). The use of the Eight-Year Cycle in the Early Malay Calendar. International Journal of Academic Research in Business and Social Sciences, 10(11), 1232-1239.

Copyright: (c) 2020 The Author(s)

Published by Human Resource Management Academic Research Society (www.hrmars.com) This article is published under the Creative Commons Attribution (CC BY 4.0) license. Anyone may reproduce, distribute, translate and create derivative works of this article (for both commercial and non-commercial purposes), subject to full attribution to the original publication and authors. The full terms of this license may be seen at: http://creativecommons.org/licences/by/4.0/legalcode

Vol. 10, No. 11, 2020, Pg. 1232 - 1239

Full Terms \& Conditions of access and use can be found at http://hrmars.com/index.php/pages/detail/publication-ethics 


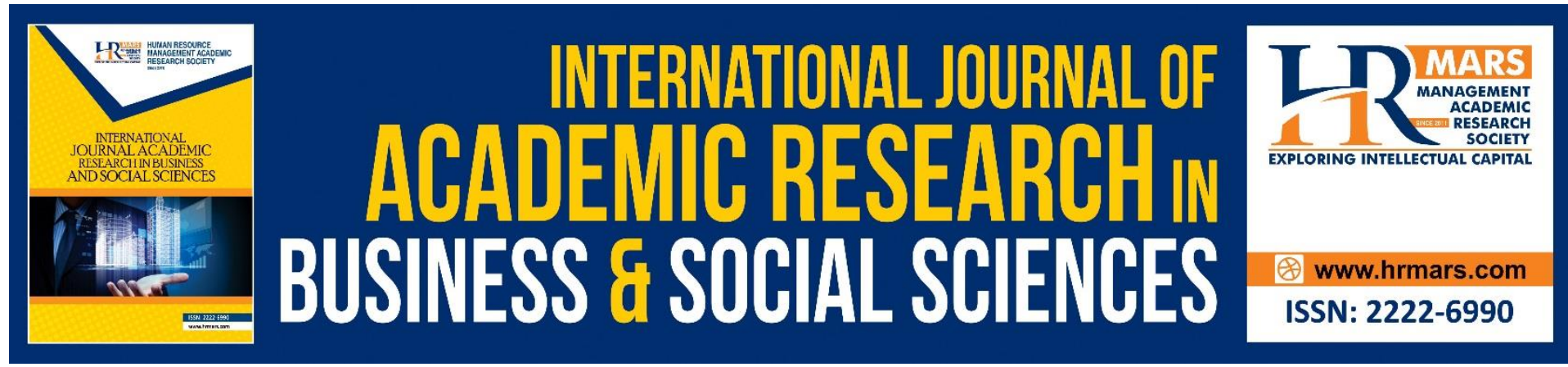

\title{
The Use of the Eight-Year Cycle in the Early Malay Calendar
}

\author{
Baharrudin Zainal, Zurita Mohd Yusoff, Jamalluddin Hashim, \\ Wan Ismail Wan Abdullah \\ Faculty of Islamic Contemporary Studies, Universiti Sultan Zainal Abidin (UniSZA), \\ Terengganu, Malaysia \\ Email: baharzai@unisza.edu.my
}

\begin{abstract}
The earliest calendar in the Malay World and throughout most of civilization, certain symbols were used to represent dates. These symbols, commonly used surrounding objects which could be collectively understood. Therefore, the calendar developed by the earliest societies correlated with basic mathematical concepts and astronomical knowledge, especially, alphabetical and numerical symbols. This paper will discuss the special codes of the calendar in the Malay World, which are based on the marking of the seasons. As in Hinduism and ethnoknowledge of society, these codes are represented by the names of local exotic animals. With the advent of Islam, these symbols were replaced by the Arabic alphabet. Quantitative analysis shows that this cycle refers more to the code of the error of the Moon phases, in relation to the actual number of days which were used to arrange the calendar.
\end{abstract}

Keywords: Calendar, Malay, Cycle, Astronomy

\section{Introduction}

The relationship between man and nature occurs when people try to understand natural phenomena, including changes in the seasons and the natural signs as a guide for human survival. Based on the geographical position of the Malay World which is located between the latitudes $15^{\circ}$ north to $15^{\circ}$ south, the effect of seasonal changes and the daily length throughout the year are not as apparent. Nevertheless, the season varies with weather changes, namely, during the rainy season, the wind scale, sea conditions and specific planting seasons. The signs of the seasons are used as a guide or a sign of the times to record the occurrence of a particular event. The earliest date, both in the Malay World and in most human civilizations, used distinctive known symbols. The symbols for these ancient dates used familiar objects from their surroundings which could be collectively understood. This led to the introduction of the alphabet and numerals to record dates and events on artifacts, monuments, tombstones, carvings and mural paintings in temples. To illustrate, in the Mayan civilization which lasted a millennium before Christ (B.C.), the calendar developed by this community is said to have a correlation with astronomical observations, mathematical concepts and symbols for alphabets and numerals (Broda, 2000). The sun is used as a measurement of a period for the solar calendar due to the influence of the Earth's rotation 
and seasonal changes. The time for the Earth's rotation around the Sun, in modern values, takes 365.242191 days, as compared to the time of 365.246667 days, as given by Ptolemy (c. 150 BC) (Ragep, 1993). To arrange the solar calendar, the value of 365.25 days per year is used with some alteration. Whereas, for the purpose of arranging the lunar calendar, alBiruni (in Kitab al-Tafhim) and Nasir al-Din al-Tusi (in Kitab al-Tadhkira) had used the average time of $354 \frac{11}{30}$ days. According to the Javanese/Islamic calendar, as modified by Sri Sultan Muhammad, from the Javanese/Hindu calendar in 1633, it applied the time period of $354 \frac{3}{8}$ days (Wardan, 1957). One month in the lunar calendar system consists of 29 or 30 days. With advances in methods of calculation, the lunar calendar was arranged using to the number of days accumulated over 30 years, to total up to , 10631.01204 days (ie; 29.530589 days $\times 12$ months $\times 30$ years). Small fractions are avoided or omitted. By rounding up the number of days to 10631 days, the 30-year cycle is divided into 19 normal years containing 354 days, and 11 leap years, comprising 355 days. In the Javanese/Islamic calendar, a normal year is named as the short year (wastu), while a leap year is referred to as the long year (wuntu).

\section{Research Method}

This article uses the document analysis method, which focuses on the interpretation of the preparation of pre-modern luni solar calendar, as mentioned in the literature review. Based on the analytical theme of acquiring the use of the eight-year cycle, the calculation uses the period movement of the Sun and Moon, which totals to 354.375 days per year. Subsequently, the number of the days in an eight-year cycle is calculated as the sum of even days for one lunar year (354 or 355 days), with a remaining number of days left. These remaining days elucidates the usage of the eight-year cycle in the early Malay calendar.

\section{The Use of 'Cycle' in the MALAY Hijri Calendar}

The use of chronological dates based on celestial objects is among the earliest ideas of astronomy in the Malay World. According to Shaharir (2000), a majority of inscriptions found in the Malay World do not have precise figures or characters. Instead, the inscriptions bore symbolic words which represented chronological dates in the form of numbers. For example, the Amoghapasa temple in Padang Candi Sumatra, uses the Sun symbol to represent the number twelve (12). The use of these symbols unlocks more complex questions on the relation between figures and the understanding of astronomy in the Malay World. This is as there are twelve constellations in the Sun's path in one solar year. These constellations, are also referred to as the zodiac, or the Twelve Stars, as known in the Malay World. Hence, a common knowledge existed in all civilizations preceding the Malay World, whether in regards to forms of constellation, symbols and names of constellations.

There are at least three uses of the constellation signs that are associated with the calendar, namely: (a) the names of months, (b) names of the years in the twelve-year cycle, and (c) as a symbol that is said to influence man and nature. The list of names of the zodiac used in the Java / Hindu calendar cycle of twelve years are; Mesa, M'risa, M'rituna, Kalakata, Sing'ha, Kanya, Tula, Mri-Chika, Danu, Makara, Kuba and Mena (Raffles, 1965). In a sevenday week system, the Javanese / Hindu calendar uses the names; Diti, Soma, Ang'gara, B'udha, Raspat'i, Sukra and Sanischara. The Javanese calendar also has a five-day week system called 'pasaran days', i.e. pahing, pon, wagi, kaliwon and legi. As for reference to the years, the Saka era is found to have been widely used in the Malay world. A number of dates 
on the earliest inscriptions found in various places in the Malay World also indicates the calendar year referred to as using the Saka era. In the Javanese/Hindu calendar, the Saka era is also known as the Java year. This illustrates the strong influence of Hinduism as a part of the features of the calendar of the Malay world prior to the advent of Islam. As the Saka era was used to refer to the calendar year due to the influence of Hinduism, the ancient Javanese calendar is a lunar-solar based calendar (Iuni-solar). However, due to seasonal recurrence of the Sun being more prominent for a specific period of time, this calendar is found to be similar to that of the solar calendar.

According to al-Biruni in Kitab al-Tafhim, the term 'cycle' is an Arabic calendar term, 'al-adwa" which means regular repetitive cycles. In the Hindu calendar, this cycle is called ' $w i n d u$ '. This cycle is needed in the arrangement of the calendar for the purpose of elimination and adjustment of error-days. The 30-year cycle is used in several types of lunar calendars as a method of accumulation of days for the arrangement of a calendar, or as a more empirical method. For example, to eliminate an error-day of 0.25 days in the Persian calendar, a 120year cycle is used so that one month may be added to the respective calendar. In the Javanese/Hindu calendar, the seven, twelve, twenty and thirty-year cycles are used (Raffles, 1965).

In the seven-year cycle, the names of the days for the early part of the year are matched with the names of disctinct animals, namely; Friday for the year of the shrimp (mangkara), Saturday for the year of the goat (menda), Sunday for the year of the centipede (klabang), Monday for the year of the worm (wichitra), Tuesday for the year of the fish (mintuna), Wednesday for the year of the scorpion (was) and Thursday for the year of the buffalo (maisaba). In the Javanese/Islamic calendar, the seven-year cycle was converted to eight years and the name of the days for the early part of the year was replaced with the alphabet/letter of the year. The modification of the Javanese/ Hindu calendar with the Saka era in the Javanese/Muslim calendar was implemented by Sri Sultan Muhammad of the Mataram kingdom, also known as Sultan Agung Prabu Hanyokrokusuma in $1633 \mathrm{M}$. According to Wardan (1957); Sastramidjaja (1991) and Suwardi (2005), the modification began in the new year of 1555 Saka, on 1 Muharram in the Hijri year 1043, to later on become the first of Muharram, in 1555, in the Saka or Javanese year. The corresponding Miladi date is 8 July 1633 , Friday. Among the new calendar mechanisms in the Javanese/Islamic system, included the construction of dates using the formulated Hijri calender (istilahi) method, but still coupled with the Saka era, or Javanese year, other than the Hijri year. This step also involved the introduction of the year's alphabet to the eight-year cycle, modification methods for the correction of error-days which occurrs every 120 years, and the methods for determining normal years as well as leap years (Wardan, 1957).

Since the modification, up until the early 20th century, the Javanese/Muslim Hijri Calendar has gone through correction methods at least three times to eliminate error-days. A greater concern, according to Sastramidjaja (1991), was the lack of calendar adjustment methods by several Javanese rulers. The use of the Javanese year, also referred to as the Saka era, also did not remain in use, instead when this calendar became widely used in the Malay World, the reference to the Hijri year became fully utilized. Nevertheless, the use of the year's alphabet in the eight-year cycle remains. The arrangement of alphabet in accordance with Javanese/ Islamic cycle is; alif ( I ), ha (ه), jim (ج), zai (j), dal (د), ba (ب), wau (و) and jim (ج). 
The arrangement of the Hijri calendar through the method of the year's alphabet should be used in tandem with a total of twelve-month alphabets to determine the names of days during the early month. The use of the year's alphabet in the Javanese/Islamic calendar is complex. In efforts to study the dates in the early manuscripts 'Aqa'id al-Nasafi', al-Attas (1988) has discussed several arrangements of the year's alphabet in the cycle concept and tested them with several dates which were complete with the year's alphabet. Since, the dates stated in the manuscripts is 'Rabiulakhir, year of ba (ب), 998 Hijri', are less earlier than compared to the introduction of cycle in the Javanese/Islamic calendar, he concluded the existence of two types of arrangements of alphabets/letters in the Malay world: the 'small cycle' for the Malay arrangement, and the 'cycle' for the Javanese/ Islamic arrangement.

\section{Findings and Discussion}

As the use of the year's alphabet in the eight-year cycle is said to have special characteristics in the Hijri calendar of the Malay World, the analysis is carried out to investigate the use of cycle as a method of error adjustment in the number of days in the Hijri calendar. As a general calendar concept, the number of days must be compiled, and the balance of the days used to arrange the calendar should be eliminated systematically. The same situation occurs in the formulated Hijri calender which accumulates the number of days every 30 lunar years with the balance of days. If the average lunar year according to modern value is used ( 354.367068 days), the balance of 0.01204 days after 30 years (result of 10631.01204 days less 10631 days) will be increased to one day after 2491 years and must be eliminated thereafter. Nevertheless, since al-Biruni used the annual average of $354 \frac{11}{30}$ days, then this error does not exist. In addition to accumulating and eliminating the remaining number of days after 30 years, other mechanisms in the Hijri calendar is minimizing the balance of the error in number of days in one consecutive year. A larger error-day will provide significant difference between the date on the calendar and the observation of the celestial moon phases. This matter was solved by placing the leap years on suitable consecutive years. Al-Biruni in his work entitled Ghurrat-uz-Zijat placed the arrangement of leap years in the Hijri calendar to fall on the 2nd, 5th, 7th, 10th, 13th, 15th, 18th, 21st, 24th, 26th and 29th year, in a 30-year cycle (Rizvi, 1979; Goutzioupas \& lordanides, 2013).

The same arrangement, was subsequently followed by Malay astronomers in arranging the Hijri istilahi calendar. Nevertheless, in the Javanese/Islamic calendar, the arrangement of a leap year (called the long year) is made for the first eight years of the 30-year cycle. The arrangement of the leap years in the Javanese/ Islamic is taken in the 2 nd, 5 th and 8 th year. To study the error-days in the Javanese/Islamic calendar based on the use of the eight-year cycle concept, an analysis of the effect of difference of days for the first eight-year and 30year cycle is performed. For this purpose, one lunar year according to the Javanese/Islamic calendar for $354 \frac{3}{8}$, or 354.375 days is used. By using consecutive normal and leap years with a variation of days (either 354 days or 355 days), the remaining balance of the day is calculated as the balance increased, as seen in Table 1. This analysis shows that after the eighth year the error-day amounts to zero. This explains why the arrangement of the leap year in the Javanese/Islamic calendar is not the same as other formulated Hijri calendars. 
Table 1: Effect of difference of days in the eight-year cycle

\begin{tabular}{llcl}
\hline Year & $\begin{array}{l}\text { Average number } \\
\text { of days in a lunar } \\
\text { year }\end{array}$ & $\begin{array}{l}\text { Total number of days } \\
\text { in a normal (B) or leap } \\
\text { (K) year }\end{array}$ & Balance increase \\
\hline & & $354(B)$ & +0.375 days \\
$\mathbf{1}$ & 354.375 days & $355($ K) & -0.250 days \\
$\mathbf{2}$ & 354.375 days & $354(B)$ & +0.125 days \\
$\mathbf{3}$ & 354.375 days & $354(B)$ & +0.500 days \\
$\mathbf{4}$ & 354.375 days & $355($ K) & -0.125 days \\
$\mathbf{5}$ & 354.375 days & $354(B)$ & +0.250 days \\
$\mathbf{6}$ & 354.375 days & $354(B)$ & +0.625 days \\
$\mathbf{7}$ & 354.375 days & $355($ K) & 0 days \\
$\mathbf{8}$ & 354.375 days & & \\
& & &
\end{tabular}

Therefore, the use of the eight-year cycle can be validated for the purpose of eliminating error as the use of the average number of days is equivalent to 354.375 days a year for the arrangement of the calendar. After eight years, the number of average days of lunar movement will be equivalent to the number of days used to arrange the calendar. As the 30-year cycle was also used by al-Biruni to obtain the number of suitable days for the arrangement of the formulated Hijri calendars, the impact on the average period, according to the Javanese /Islamic calendar, was also manipulated, namely, 354.375 days $\times 30$ years = 10631.25 days

The balance of 0.25 days after 30 years is found to be greater as compared to the average value calculated according to the modern value which only accumulates a balance of 0.01204 days after 30 years. Instead, the number of days in the Javanese/Islamic calendar will be increased to one day after four times of a 30-year cycle, that is after 120 years. This clearly indicates that the 30-year cycle in the Javanese/Islamic calendar did not have a role in eliminating error-days, but became significant in the accumulation of a total of 10,631 days, so that the concept of the normal 19 years and 11 leap years could be used.

Furthermore, the one day increase within a period of 120 years should be eliminated by a specific mechanism which reflects the role of the 120-year cycle in the Javanese/Muslim calendar. This numerical analysis, thus, shows the purpose of the use of cycles or eight-year, 30 -year and 120-year cycle, 30 years and 120 years in the Javanese/Islamic calendar. Because the average period of the lunar year according to the Javanese/Islamic calendar is not the same as the values used by Islamic and Hindu sciences, the assumption is made that probably astronomers of the Malay World who were advisors to Sri Sultan Muhammad in the year 1633 had obtained the average value by 'reverse calculation'. With the need to maintain the concept of the eight-year cycle, using the number of days for a period of 30 years and eliminating the error-day after 120 years, the suitable average period is therefore $354 \frac{3}{8}$ (354.375 days). The use of this average value is not a problem because in the arrangement method of the calendar, the empirical value (using actual celestial movement) is obtained with the values used for the arrangement of the calendar. 
Nevertheless, for a certain period of time the manipulated value must be equivalent to the period of movement of the celestial object. The findings of this analysis raises the question, is the methodology of 'reverse calculation' a synthethis of the formulated Hijri calendars method in the Malay World? The Egyptian astronomer named Sosigenes who proposed the use of the average solar year 365.25 days to arrange the calendar in $46 \mathrm{BC}$ actually knew the average tropical year founded by Ptolemy (c. $150 \mathrm{BC}$ ) which is 365.246667 days. [See the value given by Sosigenes in Dogget (1992) and Ptolemy in Ragep (1993). Nasir al-Din al-Tusi in Ragep (1993) was found to have used the average period for the arrangement of the one year lunar calendar as $354 \frac{11}{30}$ days, while the average movement of a lunar month was obtained as 29.530574 days. Given this, it can be validated that the use of the eight-year, 30 -year and 120-year cycle in the Javanese/Islamic calendar that had widespread influence in the Malay World was an innovation in the concept of the calendar. The purpose of the use of the eight-year 'small cycle' and the 120-year 'big cycle' was to eliminate the error-day, whereas the use of the 30-year cycle was for the purpose of accumulating the suitable number of days for the arrangement of the calendar year to maintain the concept of normal and leap years.

\section{Conclusion}

An effective calendar must take into account scientific justification, social and religious needs, as well as its wide use by a community. In contrast, a calendar that is not deeply rooted in society will ultimately become extinct. The community will also gravitate towards a calendar which is closer related to their daily activities, compared with a calendar dedicated only to a particular sector or has limitations in use. Similarly with the calendar that cannot eliminate error-days or does not have an objective method of adjustment, causing the date to stray far from the natural phenomenon referred to. This gives rise to polemics of society, including matters relating to religion and culture. In the analysis of the use of the eight-year cycle, 30 years and 120 years, the study found that the purpose of the eight cycle and 120 years is to eliminate error-days, whereas, the purpose of the 30 -year cycle is to accumulate a suitable number of days for the arrangement of the calendar. The use of the eight-year cycle with the alphabetical year can be validated as a special characteristic of the Malay World Hijri calendar, as a result of complex process modifications. This process was found to involve the use of a moving average for the compilation of a specific lunar calendar, apart from its own method of alteration.

\section{References}

Sastramidjaja, A. (1991). Sunda Calendar. http://members.tripod.com/INUG/Kala.htm

Al-Attas, N. S. M. (1988). The Oldest Known Malay Manuscript: A $16^{\text {th }}$ Century Malay Translation of the 'Aqaid of al-Nasafi. Kuala Lumpur: Universiti Malaya.

Al-Biruni. (1029). Kitab al-Tafhim li-awa'il sina'at al-tanjim. Dlm. Fuat Sezgin, 1998, Islamic Mathematical And Astronomy, Vol 29. (Terj. Inggeris), Ramsay Wright, 1933. Publication of the Institute In the History of Arabic-Islamic Science. Frankfurt: Institute In the History of Arabic Science, Johann Wolfgang Goethe University.

Al-Biruni. (1048). Al-Athar al-baqiya 'an al-qurun al-haliya. DIm. Fuat Sezgin, 1998, Islamic Mathematical And Astronomy, Vol 30. Publication of the Institute In the History of Arabic-Islamic Science. Frankfurt: Institute In the History of Arabic Science, Johann Wolfgang Goethe University. 
Broda, J. (2000). Mesoamerican Astronomy and the Ritual Calendar. In Astronomy Across Cultures, The History of Non- Western Astronomy, ed. Helaine Selin. London: Kluwer Academic Publisher.

Chakrabarty, K. K. (1998). Practices of Modern Hindu Calendars. Paper presented at the International Conference On Lunar Calendar Practice: A Common Heritage In Islamic, Chinese, Hindu and Other Civilizations. Universiti Sains Malaysia \& Institut Kefahaman Islam Malaysia, November 1998.

Goutzioupas, G., \& lordanides, G. (2013). “Micropolitics" and Secondary Education Teachers' Evaluation in Greece. Multilingual Academic Journal of Education and Social Sciences, 1(1), 70-85.

Dogget, L. E. (1992). Calendars. In Seidelmann, P.K (editor), Explanatory Supplement to the Astronomical Almanac. California: University Science Books.

Encyclopaedia of Islam, The. (2000). s.v 'takwim'. New Ed, Vol X. Leiden: Brill.

Kochhar, R. (1998). Hindu Calendar's Role In Indian Science. Paper presented at the. International Conference On Lunar Calendar Practice: A Common Heritage In Islamic, Chinese, Hindu and Other Civilizations. Universiti Sains Malaysia \& Institut Kefahaman Islam Malaysia, November 1998.

Wardan, M. (1957). Hisab Urfi dan Hakiki. Jogjakarta: Penerbit \& Toko Buku Siaran.

Nadvi, S. S. (1946). Muslim Observatory. Dlm. Fuat Sezgin, 1998, Islamic Mathematical and Astronomy, Vol 94. Observatories and Instruments. Publication of the Institute In the History of Arabic-Islamic Science. Frankfurt: Institute in the History of Arabic Science, Johann Wolfgang Goethe University.

Raffles, T. S. (1965). The History of Java. Kuala Lumpur: Oxford University Press

Ragep, F. J. (1993). Tadhkira fi cilm al-hay'a: Nasir al-Din Tusi's Memoir on Astronomy . New York: Springer-Verlag.

Rizvi, S. S. H. (1979). A Newly Discovered Book of al-Biruni, 'Ghurrat-uz-Zijat', and al-Birunis Measurements of Earths Dimension. DIm al-Biruni Commemorative Volume, ed. by Hakim Mohammed Said. Karachi: Hamdard Academy.

Zain, S. M. (2000). Angka Melayu Sebelum Kedatangan Islam. Bull. Malaysian Math. Sc. Soc. (Second Series), 23 (2000), ms 187-220.

Endraswara, S. (2005). Budaya Jawa, Mutiara Adiluhung Orang Jawa. Yogyakarta: Gelombang Pasang. 